\title{
The Role Of Fiscal DeCENTRALIZATION IN MUNiCipal BUdGets: Case of The Czech Republic
}

\author{
Břetislav Andrlík ${ }^{1}$, Martina Halamová ${ }^{2}$, Lucie Formanová ${ }^{3}$
}

\begin{abstract}
Immovable property tax is one of the key elements of fiscal decentralization in the Czech Republic. It is the only tax that is directed to municipal budgets in the full amount. It is also the only tax the total receipts of which can be influenced by municipalities by means of corrective features. Although the significance of immovable property tax in the process of fiscal decentralization is undeniable, its role in municipal budgets is much discussed. The goal of the article is to evaluate the role of immovable property tax in budgets of Czech municipalities through its impact on the resulting balance of financial management of a particular municipality. The role of immovable property tax is assessed against its importance for the municipal budget. The data concerning financial management of municipalities, the amount of receipts of immovable property tax and the possibilities of utilization of the local coefficient in the year 2019 are analyzed in detail. The results identified by the analysis are compared with the situation in 2012 and it may be stated that although the role of immovable property tax in municipal budgets has decreased if compared with the year 2012, it still represents a significant income of Czech municipalities. At the same time, the current economic situation suggests that the importance of immovable property tax will increase in the years to come.
\end{abstract}

\section{Keywords}

Immovable Property Tax, Local Coefficient, Fiscal Decentralization, Municipal Budget, Budget Balance

\section{Introduction}

Property taxes form a traditional part of tax systems. According to OECD (2020), taxes on property are included into group 4000 and are defined as "recurrent and non-recurrent taxes on the use, ownership or transfer of property". As part of the definition, OECD

\footnotetext{
${ }^{1}$ Mendel University in Brno, Faculty of Business and Economics, Zemědělská 1, 61300 Brno, Czech Republic. E-mail: xandrlik@mendelu.cz.

${ }^{2}$ Mendel University in Brno, Faculty of Business and Economics, Zemědělská 1, 61300 Brno, Czech Republic. E-mail: xhalamov@node.mendelu.cz.

${ }^{3}$ Mendel University in Brno, Faculty of Business and Economics, Zemědělská 1, 61300 Brno, Czech Republic. E-mail: xformano@mendelu.cz
} 
(2020) includes the following items into property taxes: taxes on immovable property or net wealth, taxes on the change of ownership of property through inheritance or gift, and taxes on financial and capital transactions. Kubátová (2018) mentions that the taxation of property ensures the essential criterion of fairness in the form of the ability-to-pay principle thanks to the reflection of wealth, and thus the taxpayer's ability to pay, in the property owned. Musgrave and Musgrave (1994) support the reasoning of property tax existence with the benefit principle, pursuant to which the value of the property increases thanks to the use of public services associated with its ownership and use.

Property taxes played the key role in tax systems of the past. Over the time their importance has been surpassed mainly by income taxes, and, since past century, also by value added taxes (Kubátová, 2018; Radvan, 2007). Therefore, the role of property taxes as public budget revenues is rather marginal at present. This trend is clearly apparent in the Czech tax environment, where the share of property taxes in the GDP lies at the bottom of European values. In 2018, this share was $0.6 \%$ of GDP, while the EU average was around $2.5 \%$ of GDP (European Commission, 2020). For a long time, the OECD has recommended governments to increase the proportion of property taxes, primarily at the detriment of more distorting taxes, such as income taxes (Hrdlička et al., 2010). Vasiliauskaite and Stankevicius (2013) reason that property taxation should be increased because of its minimal negative impact on economic growth. The same authors, as well as Andrlík (2010a) mention the stability of property taxation revenues enabling precise budgeting, which is a significant attribute particularly for indebted countries or municipalities. Zasova and Pluta (2019) stress the ability of property taxation to reduce inequality of incomes in the society, which stems from the fact that the scope of property owned is most often dependent on the income. The importance of immovable property tax for municipalities is evidenced also by Andrlík and Formanová (2014).

Political leaders tend to assume quite opposite approaches despite these recommendations. Act No. 357/1992 Coll., on Inheritance Tax, Gift Tax and Real Estate Transfer Tax, was repealed in 2013. Inheritance tax was abolished altogether, and under Act No. 586/1992 Coll. on Income Taxes, inheritance is exempt from taxes in most cases. The subjects of the Act since 2014 include also donations, which are referred to as gratuitous fulfillments. Under the Senate Ordinance No. 340/2013 Coll., on Immovable Property Acquisition Tax, the real estate transfer tax was replaced. However, with effect from 26 September 2020, it was finally decided on the abolishment of the tax (Ministry of Finance of the CR, 2020d). The only existing property tax in the Czech Republic within the OECD classification is immovable property tax at present.

Immovable property tax is regulated by Act No. 338/1992 Coll., on Immovable Property Tax, and is divided into the tax on lands and tax on buildings and dwelling units. Unlike other direct taxes (e.g. income tax) immovable property tax has not gone through dramatic changes. One of noticeable changes of legal regulation may be considered the introduction of the local coefficient in 2009, which gave municipalities, the net recipients of the tax, more powers to influence its final amount. The tax rates doubled the year after, which meant an increase in the receipts of the tax by more than CZK 2 billion (Ministry of Finance of the CR, 2010; Ministry of Finance of the CR, 2020a). The last substantial 
change was adopted in 2014 in the context of significant changes in private law leading to the origination of the new Civil Code (Andrlík and Formanová, 2015). The term real estate tax was replaced with the term immovable property tax for the sake of harmonization of both regulations.

The amount of the analyzed tax is not a substantial revenue of public budgets. The small share of immovable property tax in total tax revenues of local governments is shown in Table 1 . This share was approximately $4 \%$ in the year $2009 ; 5 \%$ in $2010-2015 ; 4 \%$ in 2016-2018; and only 3\% in 2019. The decrease in the share of the monitored tax in total tax revenues is mainly due to a more significant growth in total tax revenues and only a very low growth (or a slight decrease) in the immovable property tax revenues. Immovable property tax may be perceived as utterly insignificant in comparison with the total (national) tax revenues, as it accounts only for $1 \%$ of total tax revenues. Since 2016 this value has been below $1 \%$ and its share has a declining trend.

Table 1: Share of immovable property tax in total tax revenue of local governments (LG) (mil. CZK)

\begin{tabular}{|c|c|c|c|c|c|}
\hline & 2009 & 2010 & 2011 & 2012 & 2013 \\
\hline Total tax revenue of LG & 180,340 & 187,984 & 187,161 & 191,009 & 208,443 \\
\hline Immovable property tax & 6,320 & 8,664 & 8,609 & 9,602 & 9,736 \\
\hline \multirow[t]{2}{*}{ Immovable property tax $(\%)$} & 4 & 5 & 5 & 5 & 5 \\
\hline & 2014 & 2015 & 2016 & 2017 & 2018 \\
\hline Total tax revenue of LG & 219,391 & 226,301 & 249,498 & 270,743 & 295,190 \\
\hline Immovable property tax & 9,973 & 10,334 & 10,586 & 10,765 & 10,856 \\
\hline \multirow[t]{2}{*}{ Immovable property tax $(\%)$} & 5 & 5 & 4 & 4 & 4 \\
\hline & \multicolumn{5}{|l|}{2019} \\
\hline Total tax revenue of LG & 320,174 & & & & \\
\hline Immovable property tax & 10,909 & & & & \\
\hline Immovable property tax $(\%)$ & 3 & & & & \\
\hline
\end{tabular}

Source: Ministry of Finance of the CR, 2020a; Ministry of Finance of the CR, 2010

Although the share of immovable property tax in the total tax receipts is not significant, there are a lot of reasons justifying its existence in the tax system of the Czech Republic. One of the advantages of the tax is its tendency to progressivity. It is based on the ability-to-pay principle and contributes to the fulfilling the redistributive role of taxes (Kubátová, 2018). Immovable property tax is thus able to reduce economic inequality in the society through higher taxation of rich taxpayers. Another argument justifying the existence of the discussed tax is supported by Andrlík (2010b), Jackson and Brown (2003), and Sedmihradská (2010), who maintain that the taxation of property leads to its better 
management. According to Kubátová (2018) an asset of immovable property tax is also the fact that its effect on labour is not distorting. Whereas income taxes are likely to demotivate taxpayers and lead to reduction of work, aiming at lower or no taxation, the tendency of immovable property tax payers to limit tax liabilities by not owning property is minimal. This is attributed to the fact that immovable property must be permanently used either for living or for business due to the fact that ownership entails lower costs than long-term lease. Another positive feature of immovable property tax is its fixed tax base restricting tax evasion (Zasova and Pluta, 2019). Andrlík and Formanová (2015) also mention the minimal sensibility of the analyzed tax to economic fluctuations, which allows for easy predictability of tax receipts.

Immovable property tax is one of the taxes whose full amount goes into one budget, i.e. into the budget of the municipality in whose cadastral district the immovable property is located. This tax is an important (and the only one, as far as taxes are concerned) instrument of their financial autonomy. The key importance of the discussed tax thus rests in its significance for municipalities, where it strengthens their independence of state or regional budget. At the same time, because its amount may be adjusted, it allows for adapting tax revenues to the specifics and needs of a municipality. In the Czech Republic, this is the only tax that may be referred to as a local tax (with a certain limitation), whereby its role in the process of fiscal decentralization, i.e. extension of fiscal powers of lower administrative units increases. According to Radvan (2007), a local tax is "a statutory levy of a monetary nature directed to the municipal budget, which may be introduced or abolished by the self-governing territorial unit and which can be influenced by that unit in any way". Immovable property tax has all the apt characteristics of a local tax, including in particular the fixed tax base disabling transfers of the subject of the tax in order to reduce tax liability; sufficiently high, stable and predictable tax receipts; easy administration handled by the relevant revenue authorities; feasibility of inspection thanks to records in the land register preventing tax evasion; and good visibility of the tax encouraging responsible conduct of local politicians due to interest of taxpayers (Sedmihradská, 2016). Although municipalities cannot entirely abolish immovable property tax, they have instruments for influencing the resulting tax receipts. Powers of municipalities concerning immovable property tax were relatively limited until the year 2008 (Sedmihradská, 2013). They could affect the rate of tax on buildings and dwelling units through coefficients multiplying the rate. This correction coefficient was determined according to the population and could be reduced by the maximum of three categories or increased by one category. Municipalities were also able to apply the coefficient only in some parts of their territories. Another coefficient (amounting to 1.5) then could be used by municipalities for the adjustment of tax rate concerning buildings and dwelling units intended for recreation or business, or those used as a garage. This coefficient applied for the entire municipal territory.

Municipalities saw an important change in 2009, when their possibilities to influence the amount of taxes were extended by the addition of a third coefficient, referred to as local coefficient, which can be introduced by municipalities at the values of $2,3,4$, or 5 . The local coefficient, unlike the first two, multiplies the resulting tax on all lands, buildings 
and dwelling units, which means the final tax receipts may be increased five times at the maximum. A certain disadvantage is that the local coefficient must apply to the entire municipality, and thus tax cannot be raised in some parts only. Nevertheless, the situation is likely to change in 2021: the government's proposal of an amendment in the area of taxation (on the agenda of the Chamber of Deputies in October 2020) includes a change in the application of the local coefficient that would enable its introduction in some parts of the municipality only. The Committee on the Budget has proposed that municipalities may apply the local coefficient in the range of 1.1 to 5 , rounded to one decimal place (Chamber of Deputies of Czech Parliament, 2020).

Thus it may be observed that legislators try to change the setting of corrective features of immovable property tax so that municipalities have more opportunities to influence the tax and can better adjust it to local conditions. At the same time, the government believes that the proposed changes will lead to a better use of corrective features, which is not exhaustive at present (Chamber of Deputies of Czech Parliament, 2020). According to information from the Financial Administration, only 624 municipalities out of the total number of 6,252 decided for the introduction of the local coefficient in 2020, which is less than 10\% (Financial Administration, 2020; ČSÚ, 2019).

Despite the above arguments supporting the existence of immovable property tax, the tax is often seen as insignificant or unfair, which leads to considerations about its abolishment. The main problem causing disapproval of immovable property tax is its understanding as a form of double taxation, due to the fact that the tax is paid on property purchased by the taxpayer with money that was taxed in the past (Andrlík and Formanová, 2015; Kubátová, 2018; Sedmihradská, 2010). Therefore, many people see the tax as unfair and demotivating. However, as pointed out by Prabhakar (2008) double taxation is present in all tax systems that include more than one type of tax. For instance, payment of value added tax may also be considered as double taxation, because taxpayers pay the tax from funds that have been taxed. The costs of the tax administration also contribute to the discussion about efficiency of the tax concerned. Based on the results presented by Pudil et al. (2003) and Andrlík (2010b) it may be observed that administrative costs regarding property taxes are very high, and thus the main criterion of tax effectiveness is not met. However, it must be noted that extremely high administrative costs were associated primarily with inheritance tax and gift tax (Andrlík, 2010b), which were abolished due to low effectiveness.

Whereas most economists are advocates of property tax, the society perceives this sphere as very unpopular mainly due to good possibility of its supervision and minimal chance to avoid tax liability (Norregaard, 2013). Since it is a direct tax, taxpayers are aware of the tax burden and they often tend to perceive it as higher than it actually is. This is emphasized by the fact that property tax is not withheld but is paid by taxpayers from their own accounts. Besides, immovable property tax is mature once or twice (if the amount of CZK 5,000 is exceeded) a year, which means that a taxpayer has to spend quite a large amount of money at a time.

The deputies of ODS (Civic Democratic Party) strived to abolish the tax in 2003. They reasoned their proposal mainly with the disproportion between the low receipts of the tax and high costs of its administration, demotivating nature of the tax, and the argument of 
double taxation (Chamber of Deputies of Czech Parliament, 2003a). Their proposed bill was finally rejected inter alia on the grounds of the importance of immovable property tax for municipalities. In its opinion of the bill, the government stated that if the bill was passed, 92\% of municipalities would suffer loss of tax revenue (the bill intended to compensate municipalities for the lost revenue through increasing shares in VAT and income taxes). Moreover, abolishment of immovable property tax would contradict the effort to strengthen municipal powers as part of public administration reform (Chamber of Deputies of Czech Parliament, 2003b). Despite the unpopularity of immovable property tax and efforts to abolish it, political leaders clearly understand the importance of the tax for municipalities and their fiscal autonomy.

The goal of this article is to perform detailed analysis and use it for the determination of the significance of immovable property tax in the Czech Republic from the viewpoint of a municipality as the net benefactor of the analyzed tax receipts. The key role of immovable property tax consists in its benefit for municipalities. On the basis of the performed analysis and identification of the importance of the tax, this article shall define the impacts of existence or nonexistence of immovable property tax on the municipal budget and its final balance. Considering the possibilities of municipalities to influence the amount of tax using corrective mechanisms, another goal hereof is to evaluate the impacts of introducing the local coefficient on the municipal financial management from the viewpoint of final tax receipts as the most significant corrective feature. This means that the importance of immovable property tax is evaluated against its potential to prevent a municipal budget deficit through its very existence. Subsequently, the importance of the tax is evaluated in terms of its ability to balance a deficit of the budget or ensure its surplus by means of introducing or increasing the local coefficient. The role of immovable property tax municipal budgets is then discussed pursuant to the results achieved.

In order to meet the goals, we have used the data on the financial management of individual municipalities and the application of the local coefficient, provided by the Financial Administration of the Czech Republic and the Ministry of Finance of the Czech Republic through the analytical section of the portal entitled "Monitor - Complete overview of public finance". The subject of the analysis has been data for the calendar year 2019. The concrete data sources are stated in the References. We have primarily used the analytical method based on detailed examination of the relevant data sets. The analysis has focused on the interrelationships between the municipal budget balance and other indicators such as total income and expenditure, revenue from immovable property tax, utilization of the local coefficient, its amount, or the population. Interim results of the analysis are subsequently compared with the results of research conducted by Andrlík and Formanová (2015) using data from 2012. The descriptive method is then used to describe the facts following from the analyzed data. In conclusion, the synthesis of the obtained findings has been made to serve as the basis for discussion and formulation of conclusions. 


\section{The Role of Immovable Property Tax in Municipal Budgets in the Czech Republic}

The full amount of immovable property tax goes to the budgets of municipalities. Table 2 below shows the proportion of immovable property tax in incomes of municipalities. The analyzed tax represents an average of $8.21 \%$ of the total tax revenues. In some municipalities, immovable property tax accounts for almost $6 \%$ of all incomes. The median of the proportion of immovable property tax in the total tax revenues is $7 \%$. Although in general, the tax does not represent a substantial income for municipalities, it cannot be considered a negligible income. It always depends on the concrete municipality because the proportion of immovable property tax in either total income or tax revenues differs among municipalities. Whereas e.g. in Volevčice (district of Most, population of 111 as per 1 January 2019 (ČSÚ, 2019)), immovable property tax accounts for more than $69 \%$, in Borek (district of Prague-East, population of 320 as per 1 January 2019 (ČSÚ, 2019)), the tax represent only $0.02 \%$ of all tax revenues of the municipality. Most often, the structure of real estate in the given municipality plays the most important role. Municipalities where the tax forms an absolute majority of tax revenues are usually located in industrial regions and their high revenues are primarily attributed to the high tax liability of industrial facilities (power plants, big companies etc.). Such municipalities tend to use the highest possible values of the local coefficient, which increases the resulting tax receipts up to fivefold. However, many municipalities achieve significant incomes even without the application of the local coefficient. The above mentioned Volevčice collect the highest immovable property tax of all Czech municipalities without the use of the local coefficient due to the presence of CCGT Power Plant Počerady in its territory.

Table 2: The significance of immovable property tax in the budget of municipal units in 2019

\begin{tabular}{|l|c|c|c|}
\hline & Average & Maximum & Minimum \\
\hline $\begin{array}{l}\text { The share of immovable property tax in the total } \\
\text { municipality tax revenue (\%) }\end{array}$ & 8.21 & 69.10 & 0.02 \\
\hline $\begin{array}{l}\text { The share of immovable property tax in the total } \\
\text { municipality income (\%) }\end{array}$ & 5.84 & 63.42 & 0.01 \\
\hline
\end{tabular}

Source: Ministry of Finance of the CR, 2020a; Ministry of Finance of the CR, 2020b; Ministry of Finance of the CR, 2020c

The goal of the article is to evaluate the significance of immovable property tax for municipal budgets. First, the financial management of municipalities and balances of their budgets must be examined. Over 72\% of municipalities ran a budget surplus in 2019 . Their incomes often significantly exceeded their expenditures. 1,714 municipal units, i.e. $27.42 \%$ ended the year with a budget deficit. The largest proportion of municipalities whose incomes were not sufficient to cover all the expenses in 2019 was represented by medium-sized units (2,001-8,000 inhabitants). More than $41 \%$ of municipalities ran a deficit in this group. In the group of small municipalities (population 2,000 and less), $26 \%$ ended the year with a deficit; among the largest ones (8001 and more inhabitants), $38 \%$ ran a deficit. It may be said that municipalities managed their finance well in the 
monitored year, and almost three quarters of them reported surplus. This means that it was mostly the medium-sized municipal units that had to face insufficient income versus the expenditure incurred.

Of the 1,714 municipalities where a budget deficit has been identified, only 192, i.e. $11.20 \%$, used the local coefficient. Among the municipalities whose income exceeded the expenditure, 407, i.e. $8.97 \%$ applied the local coefficient in 2019. More often the coefficient was utilized by units running a deficit. This may be explained by the effort of the units with a long-term deficit to reduce the deficit or attain a surplus. It may also be interpreted in such a way that the local coefficient is not a sufficiently strong tool leading to higher revenues at present. Although municipalities use the local coefficient, they are not able to achieve a positive balance of their budgets by its means. Thus, it is possible that municipalities do not exploit the coefficient to its maximum or that immovable property tax does not represent an amount significant enough to balance the budget even if it is multiplied by the coefficient.

Table 3: The relation between the budgetary balance and application of the local coefficient in 2019

\begin{tabular}{|l|c|c|c|}
\hline & Total & $\begin{array}{c}\text { Municipalities with } \\
\text { local coefficient }\end{array}$ & $\begin{array}{c}\text { Municipalities with (\%) } \\
\text { local coefficient }\end{array}$ \\
\hline Municipalities with budget deficit & 1,714 & 192 & 11.20 \\
Municipalities with budget surplus & 4,538 & 407 & 8.97 \\
\hline
\end{tabular}

Source: Ministry of Finance of the CR, 2020a; Ministry of Finance of the CR, 2020b; Ministry of Finance of the CR, 2020c

The importance of immovable property tax for municipal budgets will be assessed from two viewpoints. Firstly, its importance will be evaluated against the impact of the potential loss of immovable property tax receipts on the total balance of municipal finance. In other words, we will assess what would the non-existence of immovable property tax mean for municipal budgets with a deficit. The findings will suggest to what degree Czech municipalities depend on immovable property tax. Subsequently, the relevance of the discussed tax will be viewed from the point of fiscal decentralization. The relevance of the tax for municipal budgets will be evaluated on the basis of possibilities to improve municipal financial management, for instance to reduce the budget deficit, through the application of corrective features of the tax. The impact of the local coefficient on the resulting balance of the budget will be examined, because the local coefficient may be considered an important tool leading to the increase of immovable property tax receipts. The immovable property tax significance will be assessed according to its ability to enable municipalities obtain sufficient revenues to cover all the expenditure.

The above mentioned data show that most municipal units were in surplus in 2019. The expenditure was lower than the income in most of the units. The situation is illustrated by Figure 1. The total municipal income was more than CZK 360 billion in 2019 . The total expenditure was approximately CZK 335 billion. The total surplus was CZK 25.5 billion. These data suggest that the municipalities would have reached surplus even 
without immovable property tax, whose overall receipts in 2019 were approximately CZK 11 billion. If these data are compared with the results of Andrlík and Formanová (2015), who examined data from the year 2012, a distinct difference is observed. In their research the authors concluded that if immovable property tax was abolished, the total income of municipalities would only reach $98 \%$ of their total expenditure. The total balance of municipal budgets would thus change from surplus to deficit. In 2019, on the other hand, municipalities ran such a significant surplus that not even the loss of the analyzed tax amounting to CZK 11 billion would cause a lack of incomes to cover the expenses. The improvement of municipal financial management if compared with the year 2012 is attributable to the fact that while the 2019 expenditure increased by approximately $43 \%$, the income increased by more than $51 \%$. The growth of income between the compared years was by almost ten percentage points higher.

Figure 1: The comparison of the total income and expenditure of municipalities in 2019 (in millions CZK)

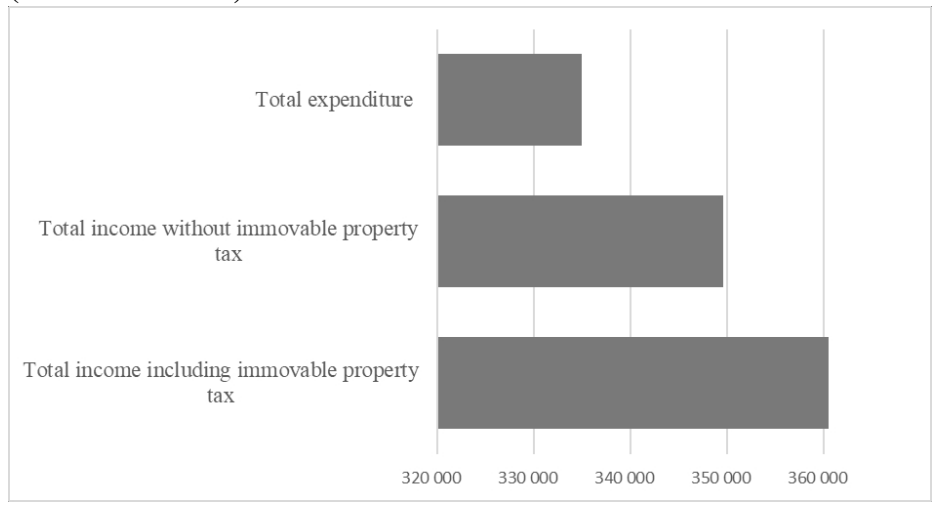

Source: Ministry of Finance of the CR, 2020a; Ministry of Finance of the CR, 2020b; Ministry of Finance of the CR, 2020c

In case immovable property tax was present in the income of municipal budgets, $27 \%$ of municipalities ended the year 2019 with a budget deficit, and $73 \%$ with a surplus. Total income exceeded total expenditure in most municipal units. Table 4 shows how the data change if immovable property tax is not present in the income. $37 \%$ of municipalities would run a budget deficit in such case, which means an increase by $10 \%$ if compared with the above situation. In absolute numbers, 2,312 municipalities would be in deficit instead of the previous 1,714 if immovable property tax was abolished. The total increase would be 598 municipal units. If we compare the current situation with the results of Andrlík and Formanová (2015), a marked improvement in the financial management of Czech municipalities is apparent. In 2012, the total of 2,324 municipalities ran a budget deficit. If the analyzed tax was abolished, the number would raise to 3,529, which is an increase by 1,205 units (Andrlík and Formanová, 2015). The number of municipalities that would not be able to cover all their expenditure without immovable property tax has decreased by a half if compared with the year 2012 . 
Table 4: The relation between the budgetary balance and application of the local coefficient in 2019

\begin{tabular}{|l|c|c|c|c|}
\hline & \multicolumn{2}{|c|}{$\begin{array}{c}\text { With immovable } \\
\text { property tax receipts }\end{array}$} & \multicolumn{2}{c|}{$\begin{array}{c}\text { Without immovable } \\
\text { property tax receipts }\end{array}$} \\
\hline Municipalities with budget deficit & 1,714 & $27 \%$ & 2,312 & $37 \%$ \\
\hline Municipalities with budget surplus & 4,538 & $73 \%$ & 3,940 & $63 \%$ \\
\hline
\end{tabular}

Source: Ministry of Finance of the CR, 2020a; Ministry of Finance of the CR, 2020b; Ministry of Finance of the CR, 2020c

In terms of size of municipalities, the loss of immovable property tax would most severely affect large units with 8,000 plus inhabitants. In consequence of a loss of tax revenues, the number of municipalities with a budget deficit would rise by more than $18 \%$, which is almost a twofold increase than the case would be in smaller units. This is mainly attributed to the amount of immovable property tax. Under standard circumstances (i.e. the municipality is not located in a tourist area and there is no taxpayer with a distinctly high tax liability in its cadastral district, e.g. an owner of a power plant or a big company), the amount of the tax is dependent on the population. The number of inhabitants is related to the amount of immovable property taxed. At the same time, cadastral districts of municipalities with larger population register immovable property which is subject to higher tax rates (e.g. property used for business purposes). Whereas the loss of immovable property tax in smaller municipalities represents a loss of funds amounting to tens or hundreds of thousands CZK, larger municipalities would face a loss of millions CZK (Ministry of Finance of the CR, 2020a).

Table 5: The relation between the income of municipal units with/without immovable property tax (IPT) receipts, and the number of inhabitants in 2019

\begin{tabular}{|l|c|c|c|c|c|c|}
\hline & $\begin{array}{c}\text { Total number } \\
\text { of municipalities }\end{array}$ & \multicolumn{2}{|c|}{$\begin{array}{c}\text { Budget deficit } \\
\text { with IPT receipts }\end{array}$} & \multicolumn{2}{|c|}{$\begin{array}{c}\text { Budget deficit } \\
\text { without IPT receipts }\end{array}$} & Increase \\
\hline$\leq 2,000$ inhab. & 5,549 & 1,429 & $25.75 \%$ & 1,945 & $35.05 \%$ & $9.30 \%$ \\
\hline $2,001-8,000$ inhab. & 539 & 223 & $41.37 \%$ & 275 & $51.02 \%$ & $9.65 \%$ \\
\hline$\geq 8,001$ inhab. & 164 & 62 & $37.80 \%$ & 92 & $56.10 \%$ & $18.29 \%$ \\
\hline
\end{tabular}

Source: Ministry of Finance of the CR, 2020a; Ministry of Finance of the CR, 2020b; Ministry of Finance of the CR, 2020c

Based on the above results, it may be stated that the importance of the tax in terms of its ability to influence the final budget balance decreased in 2019 if compared with 2012 . However, the abolishment of the tax would put 598 municipalities, i.e. almost $10 \%$ of all municipalities in the Czech Republic, in deficit. It has been observed that immovable property tax plays a more substantial role in the budgets of large (in terms of population) municipalities. The loss of the tax would lead to the deficit in $18.29 \%$ of them. This would include towns that use the local coefficient (16 of them use the coefficient 2 , including 
Český Krumlov, Cheb, Karlovy Vary, Litovel, Kutná Hora or Uherské Hradiště), as well as those which do not use it (14 towns, including Brno, Olomouc, Hořice, Náchod, Svitavy or Třinec).

The importance of immovable property tax can also be evaluated in terms of improving financial management of the municipality by means of corrective features, specifically of the local coefficient. The impact of introducing the local coefficient on the reduction of budget deficit is shown in Table 6. Of the total number of 1,714 units that were in deficit in $2019,1,522$, i.e. $89 \%$ do not use the local coefficient at all. These municipalities would achieve the surplus of their budgets in $56.77 \%$ cases by the introduction of the local coefficient of 2, 3, 4 or 5. The coefficient of 2, which does not pose an extraordinary increase of tax burden, would be sufficient for $20 \%$ of them. 658 of the municipalities that do not use the local coefficient at present would not achieve a surplus of their budgets even if they applied the maximum value 5 of the coefficient.

The municipalities that use the local coefficient in the values of 2,3 , or 4 (187 of them) would gain a surplus in $63.64 \%$ of cases if they increased the coefficient value. Almost $65 \%$ of municipalities using the local coefficient of 2 would achieve a budget surplus through its increase to values 3,4 , or 5 . Where municipalities apply the local coefficient of 3 , increasing its value to 4 or 5 would help to balance the budgets of 18 municipalities, i.e. $62 \%$. The local coefficient of 4 is used by 7 municipalities running a budget deficit. Three of them would reach positive numbers by increasing its value to the maximum of 5 . The total of $68(36.36 \%)$ municipalities using the local coefficient as per 1 January 2019 would not achieve a surplus even if they applied the value of 5 (5 municipalities use the local coefficient of 5 and yet run a deficit).

Table 6: The improvement of the budgetary balance after applying local coefficient (LC) in 2019

\begin{tabular}{|c|c|c|c|c|c|c|c|c|}
\hline & \multicolumn{2}{|c|}{$\begin{array}{l}\text { Municipalities } \\
\text { without LC }\end{array}$} & \multicolumn{2}{|c|}{$\begin{array}{l}\text { Municipalities } \\
\text { with LC } 2\end{array}$} & \multicolumn{2}{|c|}{$\begin{array}{l}\text { Municipalities } \\
\text { with LC } 3\end{array}$} & \multicolumn{2}{|c|}{$\begin{array}{l}\text { Municipalities } \\
\text { with LC } 4\end{array}$} \\
\hline Municipalities with & \multicolumn{2}{|c|}{1,522} & \multicolumn{2}{|c|}{151} & \multicolumn{2}{|c|}{29} & \multicolumn{2}{|c|}{7} \\
\hline $\begin{array}{l}\text { Budget surplus } \\
\text { with LC } 2\end{array}$ & 309 & $20.30 \%$ & & & & & & \\
\hline $\begin{array}{l}\text { Budget surplus } \\
\text { with LC } 3\end{array}$ & 226 & $14.85 \%$ & 51 & $33.77 \%$ & & & & \\
\hline $\begin{array}{l}\text { Budget surplus } \\
\text { with LC } 4\end{array}$ & 181 & $11.89 \%$ & 22 & $11.57 \%$ & 12 & $41.38 \%$ & & \\
\hline $\begin{array}{l}\text { Budget surplus } \\
\text { with LC } 5\end{array}$ & 148 & $9.72 \%$ & 25 & $16.56 \%$ & 6 & $20.69 \%$ & 3 & $42.86 \%$ \\
\hline $\begin{array}{l}\text { Budget deficit even } \\
\text { with LC } 5\end{array}$ & 658 & $43.23 \%$ & 53 & $35.10 \%$ & 11 & $37.93 \%$ & 4 & $57.14 \%$ \\
\hline
\end{tabular}

Source: Ministry of Finance of the CR, 2020a; Ministry of Finance of the CR, 2020b; Ministry of Finance of the CR, 2020c 
In total, 1,714 municipalities run a budget deficit. 1,709 municipalities do not apply any local coefficient or apply it in the values of 2,3 , or 4 . These municipalities could obtain additional revenues from immovable property tax by introducing or increasing the local coefficient (by one or three levels). Of this number, 983 (57.52\%) municipalities would achieve a budget surplus through the introduction or increase of the local coefficient. On the other hand, the deficit of $726(42.48 \%)$ such municipalities is so high that even a fivefold increase in immovable property tax revenue would not offset the deficit. These municipalities are characterized by a low number of inhabitants (median of 544), immovable property tax revenues below CZK 1 million (median of CZK 645 thousand), and a deficit exceeding CZK 2 million (median of CZK 2.2 million) (Ministry of Finance of the CR, 2020b; Ministry of Finance of the CR, 2020c).

\section{Conclusion}

Although immovable property tax does not represent significant revenue for public budgets, it plays a key role in the process of extension of municipal powers, since this is the only tax in the Czech Republic that goes to municipal budgets in full amount. At present, after the abolition of immovable property acquisition tax, it is the last remaining property tax in this country. Immovable property tax accounts for tax revenues of individual municipalities in the range of $0.02 \%$ to $69.10 \%$. The amounts of tax receipts may substantially differ among municipal units. An important role is played by the structure of immovable property and the taxpayers as well as the size of the municipality. On average, the discussed tax contributes to the total tax revenue by $8.21 \%$.

In terms of the volume of tax receipts, immovable property tax tends to be a marginal tax, nevertheless, it has certain characteristics which make it an indispensable part of the tax system. Such characteristics include for instance redistributive nature of the tax, low distorting effect, easy registration of the subject of the tax enabling good inspection leading to the minimization of tax evasion, or minimal sensitivity to economic fluctuations. Thanks to the above properties, immovable property tax is an apt tax serving local purposes. Pauličková (2010) mentions the tax powers of a municipality and their extension as one of the essential steps leading to more options of own funding and the resulting larger financial autonomy of municipalities. Although the tax may not be seen substantial in terms of receipts, it may be considered fundamental for the process of fiscal decentralization.

Within this process, municipalities are guaranteed the authority to at least partially influence the resulting amount of the tax concerned. One of the aims of the process is to enable municipalities increase their income, and more importantly, to provide a tool for adapting the tax amount to individual specifics and needs of the municipality. Besides the two coefficients multiplying the tax rate, municipalities have been entitled to apply the local coefficient which multiplies the resulting tax liability since the year 2009. The government's proposal of an amendment with expected validity since 2021 contains a provision enabling municipalities not only to apply various levels of the local coefficient, but also to apply its different values in different parts of the municipality. The current legislation thus aims at extending municipal powers in this area and better utilizing the corrective features leading to larger fiscal autonomy of municipalities. 
The goal of this article was to assess the significance of immovable property tax for municipal budgets in the Czech Republic. The significance was evaluated from the viewpoint of financial management of the municipality and the impact of introduction or adjustment of the local coefficient on the resulting balance of the budget. First it was ascertained to what extent the non-existence of the analyzed tax would affect the balance of municipal budgets. Further examination focused on the impact of introduction of the local coefficient and its application in various values on the municipal budgets running a deficit. The goal was to find out the degree of dependence of municipalities on immovable property tax and the extent to which they can improve their financial management through their power to introduce the local coefficient.

In 2019 a deficit budget was run by 1,714 municipalities of the total number of 6,252, which means that almost three quarters of municipalities had a surplus budget. The total surplus of municipalities was CZK 25.5 billion. Municipal incomes in the monitored year were markedly higher than expenditures. Due to this fact, the absence of immovable property tax would not cause an overall deficit in municipal budgets. From a standpoint of individual municipalities, it can be said that if immovable property tax was abolished, the number of municipalities with a deficit budget would increase by 10 percentage points, i.e. by 598 municipalities. In comparison with the results of Andrlík and Formanová (2015), the municipal financial management considerably improved, which means that immovable property tax has become less important. However, the calculated increase in the number of municipalities that would run a budget deficit by almost 600 may still be considered significant. The loss of revenue from immovable property tax would most severely affect large municipalities (population of 8,000 plus) where the tax represents an income of millions CZK.

As far as improvement of municipal financial management through the local coefficient is concerned, its introduction or adjustment would lead to the surplus in the budgets of $57.52 \%$ of municipalities running a deficit. Of that number, for $309(18 \%)$ municipalities would be sufficient to introduce the value 2 of the coefficient to offset the deficit. Such value would not mean a substantial increase in the tax burden. $42.48 \%$ of municipalities that do not apply the local coefficient or apply it in the value of 2, 3, or 4 (and thus can increase it) even an introduction of the value of 5 would not be sufficient to achieve a budget surplus. Such municipalities, where the local coefficient cannot sufficiently influence the budget, may be described as small municipalities (with the median of 544 inhabitants) with income of hundreds of thousands CZK and a deficit exceeding CZK 2 million.

In general, it can be said that Czech municipalities managed their finance well in 2019 and absence of immovable property tax from municipal budgets would lead to a deficit in every tenth case. This is almost a double decrease if compared with the year 2012. The importance of immovable property tax as an income of municipal budgets increased in comparison with 2012. However, the importance of the tax may be expected to rise in the following years due to the decrease in the revenue from shared taxes resulting from the economic decline in consequence of anti-epidemic measures adopted in connection with the coronavirus pandemic (С̆TK, 2020). A slump in the revenue from shared taxes should reach CZK 26.5 billion in 2020 and should be compensated for by subsidies 
amounting to CZK 12.8 billion, i.e. not even a half of the income originally expected (DVS, 2020). Municipalities will probably face a decrease in the budget surplus. Thanks to its minimal sensitivity to economic fluctuations, immovable property tax represents one of the relatively stable revenues which might help municipalities overcome the loss of incomes from the state budget. Many municipalities have responded to the situation and introduced the local coefficient multiplying the receipts of the tax in question several times, with effectiveness since 2021 (Dostál, 2020). Municipalities that have decided to apply the local coefficient since 2021 include for instance Drásov (Town of Drásov, 2020), Břidličná (City of Břidličná, 2020), Koššany (City of Košlany, 2020), Brandýs nad Labem - Stará Boleslav (City of Brandýs nad Labem - Stará Boleslav, 2020) or Hukvaldy (Municipality of Hukvaldy, 2020). A legislative effort to extend the powers of municipalities and encourage their independence of budgets of higher administrative units is currently apparent in the Czech Republic, which is specifically reflected in the larger possibilities of municipal units to influence the amount of their total tax revenue through the immovable property tax coefficients.

\section{Acknowledgements}

This paper was supported by the Internal Grant agency PEF MENDELU [PEF_TP_2020007].

\section{References}

Act. No. 338/1992 Sb., o dani z nemovitých věcí, ve znění pozdějších předpisů.

Andrlík, B. (2010a). Vývoj inkasa transferových daní v letech 1993 až 2009 v České republice. Acta Universitatis agriculturae et silviculturae Mendelianae Brunensis, 58(6), $21-32$.

Andrlík, B. (2010b). Administrativní náklady majetkových daní v České republice. Acta Universitatis agriculturae et silviculturae Mendelianae Brunensis, 58(6), 13-20.

Andrlík, B., Formanová, L. (2014). Importance of the recurrent tax on immovable property in the tax systems of EU countries. Acta Universitatis agriculturae et silviculturae Mendelianae Brunensis, 62(6), 1213-1220.

Andrlík, B., Formanová, L. (2015). The role of the tax on immovable property in the municipal budgets in the Czech Republic. Acta academica karviniensia, 2015(2), 5-17. Chamber of Deputies of Czech Parliament (2003a). Sněmovní tisk 218/0. Retrieved September 23, 2020, from https://www.psp.cz/sqw/text/orig2.sqw?idd=6362.

Chamber of Deputies of Czech Parliament (2003b). Sněmovní tisk 218/1. Retrieved September 23, 2020, from https://www.psp.cz/sqw/text/tiskt.sqw?O=4\&CT=218\&CT1=1. Chamber of Deputies of Czech Parliament (2020). Sněmovní tisk 910. Retrieved September 23, 2020, from https://www.psp.cz/sqw/historie.sqw?o=8\&t=910.

City of Brandýs nad Labem - Stará Boleslav (2020). Obecně závazná vyhláška města Brandýs nad Labem - Stará Boleslav č. 4/2020 o stanovení koeficientu pro výpočet daně z nemovitých věcí. Retrieved October 27, 2020, from https://www.brandysko.cz/assets/ File.ashx?id_org=904\&id_dokumenty=55138. 
City of Břidličná (2020). Obecně závazná vyhláška č. 1/2020, o stanovení místního koeficientu pro výpočet daně z nemovitých věcí. Retrieved October 27, 2020, from https://www. mu-bridlicna.cz/16514-obecne-zavazna-vyhlaska-c-12020-o-stanoveni-mistniho-koeficientu-pro-vypocet-dane-z-nemovitych-veci.

City of Koštany (2020). Obecně závazná vyhláška č. 1/2020, o stanovení místního koeficientu pro výpočet daně z nemovitých věcí. Retrieved October 27, 2020, from https://www. kostany.cz/wp/wordpress/wp-content/uploads/2020/09/OZV_1-2020-koeficient_dane.pdf. ČSÚ (2019). Počet obyvatel v obcích $-k$ 1. 1. 2019. Retrieved February 2, 2020, from https://www.czso.cz/csu/czso/pocet-obyvatel-v-obcichza0wri436p.

ČTK (2020). Obce a kraje přijdou kvůli koronaviru o více než 30 miliard, odhaduje ministerstvo financí. Retrieved October 15, 2020, from https://domaci.ihned.cz/c1-66755910-prijmy-obci-a-kraju-klesnou-o-deset-procent-zmeny-v-rozpoctovem-urcovani-daniministerstvo-nechysta.

Dostál, J. (2020). Výpadek př́jmů zalepí z peněz lidí. Jihomoravská města zvyšují daň z nemovitosti. Retrieved October 27, 2020, from https://brnensky.denik.cz/z-regionu/vypadek-prijmu-zalepi-z-penez-lidi-jihomoravska-mesta-zvysuji-dan-z-nemovitosti.html.

DVS (2020). Obce letos přijdou na sdílených daních o téměr 27 miliard, se kterými počítaly ve svých rozpočtech. Retrieved September 29, 2020, from http://www.dvs.cz/clanek.asp? $\mathrm{id}=6796157 \& \mathrm{ht}=\mathrm{p} \% \mathrm{~F} 8 \%$ EDjmy+obce.

European Commission (2020). Taxation Trends in the European Union. Retrieved September 23, 2020, from https://ec.europa.eu/taxation_customs/sites/taxation/files/taxation_trends_report_2020.pdf.

Financial Administration (2019). Informace poskytnuté dle zákona č. 106/1999 Sb., (050/2019). Retrieved April 24, 2020, from https://www.financnisprava.cz/cs/financnisprava/generalni-financnireditelstvi/uredni-deska-gfr/poskytnute-info-dle-zakona-106$1999 \mathrm{sb} / 2019$.

Financial Administration (2020). Informace poskytnuté dle zákona č. 106/1999 Sb., (002/2020). Retrieved April 22, 2020, from https://www.financnisprava.cz/cs/financnisprava/generalni-financnireditelstvi/uredni-deska-gfr/poskytnute-info-dle-zakona-106$1999 \mathrm{sb} / 2020$.

Hrdlička, Z. et al. (2010). Further Advancing Pro-growth Tax and Benefit Reform in the Czech Republic. OECD Economics Department Working Papers, No. 758, https://doi.org/ $10.1787 / 5 \mathrm{kmh} 5 \mathrm{gmx} 8 \mathrm{~h} 9 \mathrm{p}-\mathrm{en}$.

Jackson, P. M., Brown, C. V. (2003). Ekonomie veřejného sektoru (1st ed.). Praha: Eurolex Bohemia.

Kubátová, K. 2018. Daňová teorie a politika (7th ed.). Praha: Wolters Kluwer.

Ministry of Finance of the CR (2010). Návrh státního závěrečného účtu české republiky za rok 2009, C. Zpráva o výsledcích hospodaření státního rozpočtu. Retrieved September 23, 2020, from https://www.mfcr.cz/cs/verejny-sektor/statni-rozpocet/plnenistatnihorozpoctu/2009/statni-zaverecny-ucet-za-rok-2009-2046.

Ministry of Finance of the CR (2020a). Monitor: Kompletní přehled veřejných financí. Retrieved September 23, 2020, from https://monitor.statnipokladna.cz/. 
Ministry of Finance of the CR (2020b). Porovnání finančních a účetních ukazatelů (území). Retrieved September 23, 2020, from https://monitor.statnipokladna.cz/analyza/. Ministry of Finance of the CR (2020c). Př́imy a výdaje územních rozpočtů. Retrieved September 23, 2020, from https://monitor.statnipokladna.cz/analyza/.

Ministry of Finance of the CR (2020d). Daň z nabytí nemovitých věcí zrušena se zpětným účinkem k prosinci 2019. Retrieved September 23, 2020, from https://www.mfcr.cz/cs/ aktualne/tiskove-zpravy/2020/zruseni-dane-z-nabyti-nemovitych-veci-se-38157. Municipalities. Lex Localis - Journal of Local Self-Government, 14(1), 75-92.

Musgrave, R. A., Musgrave, P. B. (1994). Veřejné finance v teorii a praxi. Praha: Management Press.

Norregaard, J. (2013). Taxing Immovable Property - Revenue Potential and Implementation Chalenges. International Monetary Fund: Working paper, 13/129.

OECD. (2020). Tax on property (indicator). Retrieved September 23, 2020, from https:// data.oecd.org/tax/tax-on-property.htm.

Pauličková, A. (2010). Economic Crisis and Enhanced Competitiveness of Municipalities. DANUBE: Law and Economics Review, 2010(4).

Prabhakar, R. (2008). Wealth Taxes: Stories, Metaphors and Public Attitudes. The Political Quarterly, 79(2): 172-178.

Pudil, P., Vybíhal, V., Vítek, L., Pavel, J. et al. (2004). Zdanění a efektivnost (1st ed.). Praha: Eurolex Bohemia.

Radvan, M. (2007). Zdanění majetku v Evropě. Prague: C. H. Beck. Republic and Slovakia. Acta Oeconomica Pragensia, 21(1), 68-80.

Sedmihradská, L. (2010). Property Tax as a Key Tool for Fiscal Decentralisation: Unfulfilled Expectationsin Central and Eastern European Countries. In: Sedmihradská, L. Property Tax in Economies in Transition: Selected Case Studies. Bratislava: NISPAcee. Sedmihradská, L. (2013). Property Tax Autonomy of Municipalities in the Czech. Sedmihradská, L. (2016). Municipal Tax Autonomy and Tax Mimicking in Czech. Town of Drásov (2020). Obecně závazná vyhláška městyse Drásov č. 7/2020 o stanovení koeficientu pro výpočet daně z nemovitých věcí. Retrieved October 27, 2020, from http:// www.drasov.cz/assets/File.ashx?id_org=3210\&id_dokumenty=8122.

Town of Hukvaldy (2020). Obecně závazná vyhláška č. 2/2020 o stanovení místního koeficientu pro výpočet daně z nemovitých věcí. Retrieved October 27, 2020, from https://www. hukvaldy.eu/images/uredni_deska_pdf/2020/OZV2020-02.pdf.

Vasiliauskaite, A., Stankevicius E. (2013). European property taxation: new sources of revenue, cases of the eu countries. Economics and Management, 18(3), 428-435.

Zasova, A., Pluta, A. (2019). Shifting Tax Burden from Labour to Property: The Case of Latvia. New Challenges of Economics \& Business Development, 2019, 925-937. 